\title{
EPISODIC DIAMOND GENESIS AND KAAPVAAL CRATON EVOLUTION
}

\author{
Stephen H. Richardson ${ }^{1}$, Steven B. Shirey ${ }^{2}$ and Jeffrey W. Harris ${ }^{3}$ \\ ${ }^{1}$ University of Cape Town, South Africa; ${ }^{2}$ Carnegie Institution of Washington, USA $;{ }^{3}$ University of Glasgow, UK
}

Two decades of work on the age and composition of diamonds and their syngenetic inclusions from major kimberlite localities on the Kaapvaal, Siberian and Slave cratons has firmly established that diamonds are xenocrysts in kimberlite magmas. More importantly, diamonds of different age from the same kimberlite, as well as diamonds of the same age from different kimberlites, are now providing key constraints on Archean craton evolution. Given the unique structure of diamond that can preserve inclusions as an isolated system, insights can be obtained into the age, structure, and composition of continental lithosphere as far back as the middle Archean. The Re-Os isotope system in sulfide inclusions and the $\mathrm{Sm}-\mathrm{Nd}$ and $\mathrm{Rb}-\mathrm{Sr}$ systems in silicate inclusions, coupled with nitrogen aggregation state in the host diamonds, give complementary information on the precursors of multiple generations of diamonds formed and stored in craton keels and sampled by subsequent kimberlite magmatism.

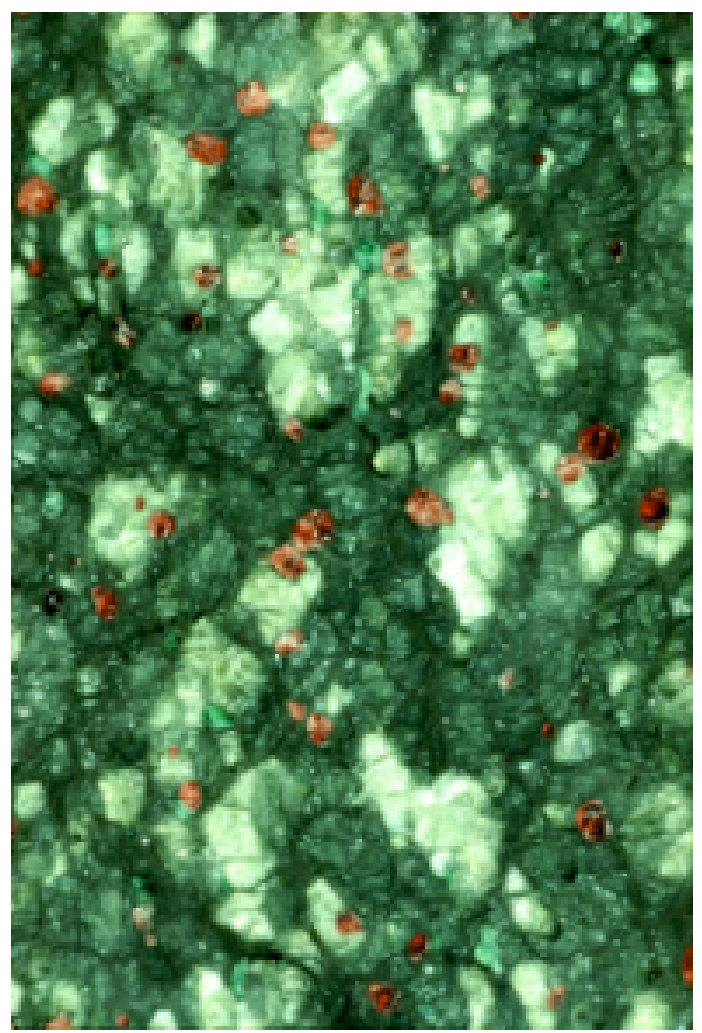

Figure 1: Garnet lherzolite xenolith AJE165 from Kimberley, a survivor of the $2.9 \mathrm{Ga}$ accretion of the western and eastern blocks of the Kaapvaal craton (specimen: 6 x $9 \mathrm{~cm}$ slab; see Richardson et al., 1985).
Conversely, xenoliths and associated macrocryst minerals provide information on subsequent mantle and lower crustal evolutionary processes up to the time of kimberlite emplacement (see Figure 1).

From a Kaapvaal craton perspective, the $85 \mathrm{Ma}$ Kimberley, 240 Ma Jwaneng and 1180 Ma Premier kimberlites are key localities with respect to characterizing the relationship between episodic diamond genesis and Archean craton evolution. The occurrence of $3.2-3.3 \mathrm{Ga}$ diamonds with depleted harzburgitic silicate inclusions ( $\mathrm{Sm}-\mathrm{Nd}, \mathrm{Rb}-\mathrm{Sr}$ model ages; Richardson et al., 1984) and 2.9 Ga diamonds with enriched eclogitic sulfide inclusions (Re-Os isochron age; Richardson et al., 2001a) in the same Kimberley kimberlites indicates that formation of the Kaapvaal craton was at least a two stage process. Considering $\mathrm{Re}-\mathrm{Os}, \mathrm{Sm}-\mathrm{Nd}$, and $\mathrm{Rb}-\mathrm{Sr}$ model age relationships for both inclusions and macrocryst minerals, a time gap of $300+/-200$ million years is required between the two Archean diamond formation events recorded in Kimberley diamonds. Thus, Kimberley, that lies on $3.2 \mathrm{Ga}$ crust, has $3.2 \mathrm{Ga}$ harzburgitic diamonds associated with creation of the western Kaapvaal cratonic nucleus, and 2.9 Ga eclogitic diamonds resulting from its accretion to the eastern Kaapvaal craton in the vicinity of the Colesberg magnetic lineament. Jwaneng, the world's most profitable mine on the western side of the combined Kaapvaal craton, has both $2.9 \mathrm{Ga}$ and $1.5 \mathrm{Ga}$ eclogitic diamonds (Figure 2) reflecting stabilization and subse-

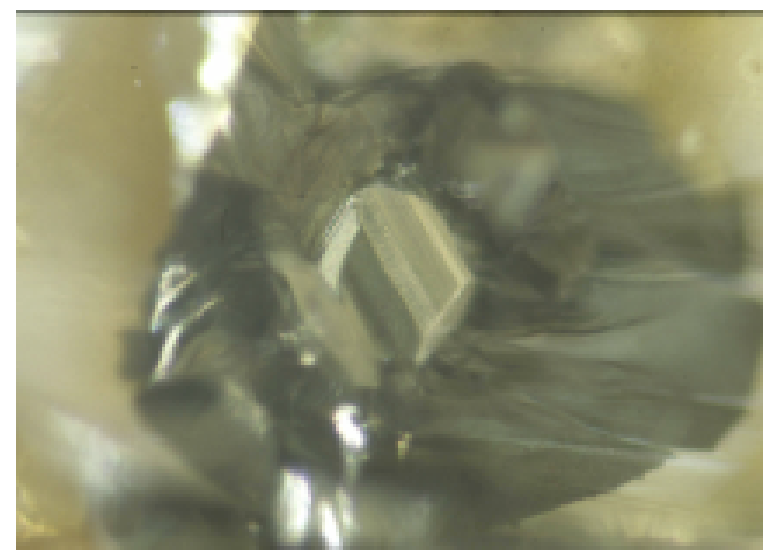

Figure 2: Sulfide inclusion surrounded by rosette fractures in a Jwaneng diamond. Width of photo $2 . .3 \mathrm{~mm}$, inclusion 300 microns (Jeff Harris photo). 
quent modification of the craton (Richardson et al., 1999; Richardson et al., 2001b). Premier, on the edge of the massive Bushveld Complex in the north-central part of the craton, has $1.9 \mathrm{Ga}$ lherzolitic diamonds that postdate Bushveld-Molopo magmatism (but whose precursors have Archean Sm-Nd model ages), as well as $1.2 \mathrm{Ga}$ eclogitic diamonds (Richardson et al., 1993; Richardson \& Harris, 1997).

The available diamond distribution, composition, and Sm-Nd and Re-Os age data support a multi-stage process to make, stabilize and modify Archean cratons (see Figure 3; Shirey et al., 2002). Mantle keels to early continental nuclei were created by severe middle Archean depletion events with high degrees of melting producing komatiites, followed by metasomatism and early harzburgitic diamond formation $(3.2-3.3 \mathrm{Ga})$. Late Archean accretionary events $(2.9 \mathrm{Ga})$ involving a subducted oceanic lithosphere component stabilized the craton and contributed eclogitic diamonds to the existing harzburgitic diamond population. Subsequent Proterozoic tectonothermal events (notably BushveldMolopo magmatism at $2.05 \mathrm{Ga}$ ) altered the composition of the cratonic keel by adding a basaltic component and subsequently introducing new generations of lherzolitic and eclogitic diamonds to an already extensive Archean diamond suite.
From an inter-craton perspective, there are also interesting parallels though similar treatment of results from the Slave and Siberian cratons is still at an early stage. For example, there is clear evidence (Westerlund et al., this volume) of a $3.2-3.4 \mathrm{Ga}$ peridotitic diamond formation event at Panda on the Slave craton. Furthermore, published data for sulfide and silicate inclusions from Udachnaya on the Siberian craton indicate both harzburgitic and lherzolitic diamond formation events at ca. 3.2 Ga and 2.0 Ga respectively (Pearson et al., 1999; Richardson \& Harris, 1997). In both cases, the host diamonds display nitrogen aggregation characteristics consistent with lithospheric mantle storage at temperatures of 1100-1200 degrees $\mathrm{C}$ for a comparable period. As at Premier on the Kaapvaal craton, the precursors of the Udachnaya lherzolitic diamonds have Archean Sm-Nd model ages. In short, the evidence for a global connection between episodic diamond genesis and Archean craton evolution is now as compelling as that for the xenocrystic relationship between diamond and kimberlite.

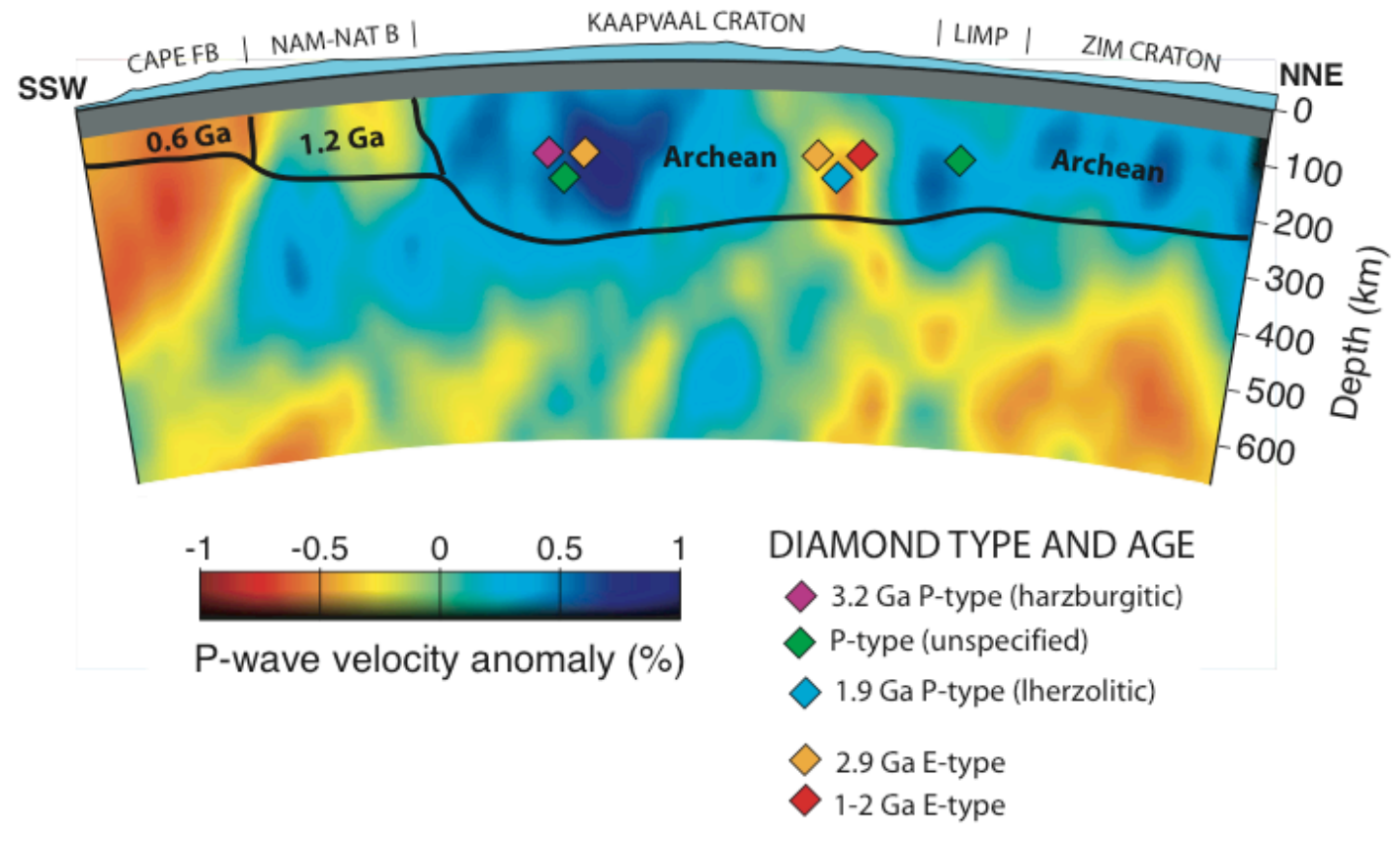

Figure 3: Tomographic cross-section of the southern African lithosphere showing the schematic distribution of different generations of peridotitic and eclogitic diamonds (after Shirey et al., 2002). 


\section{REFERENCES}

Pearson, D.G., Shirey, S.B., Bulanova, G.P., Carlson, R.W., Milledge, H.J., 1999. Re-Os isotope measurements of single sulfide inclusions in a Siberian diamond and its nitrogen aggregation systematics. Geochim. Cosmochim. Acta 63, 703-711.

Richardson, S.H., Gurney, J.J., Erlank, A.J., Harris, J.W., 1984. Origin of diamonds in old enriched mantle. Nature 310, 198-202.

Richardson, S.H., Erlank, A.J., Hart, S.R., 1985. Kimberliteborne garnet peridotite xenoliths from old enriched subcontinental lithosphere. Earth Planet. Sci. Lett. $75,116-128$.

Richardson, S.H., Harris, J.W., Gurney, J.J., 1993. Three generations of diamonds from old continental mantle. Nature 366, 256-258.

Richardson, S.H., Harris, J.W., 1997. Antiquity of peridotitic diamonds from the Siberian craton. Earth Planet. Sci. Lett. 151, 271-277.

Richardson, S.H., Chinn, I.L., Harris, J.W., 1999. Age and origin of eclogitic diamonds from the Jwaneng kimberlite, Botswana. In: Gurney, J.J., Gurney, J.L., Pascoe, M.D., Richardson, S.H. (Eds.), Proc. 7th Int. Kimberlite Conf., Vol. II: The P.H. Nixon Volume, 709-713, Red Roof Design, Cape Town.

Richardson, S.H., Shirey, S.B., Harris, J.W., Carlson, R.W., 2001a. Archean subduction recorded by Re-Os isotopes in eclogitic sulfide inclusions in Kimberley diamonds. Earth Plan. Sci. Lett. 191, 239-248.

Richardson, S.H., Shirey, S.B., Harris, J.W., Carlson, R.W., 2001b. Episodic diamond formation in the Kaapvaal craton keel. EOS, Trans. AGU 82, S444.

Shirey, S.B., Harris, J.W., Richardson, S.H., Fouch, M.J., James, D., Cartigny, P., Deines, P., Viljoen, F., 2002. Diamond genesis, seismic structure, and evolution of the Kaapvaal-Zimbabwe craton. Science 297, 1683-1686.

Contact: SH Richardson, Department of Geological Sciences, University of Cape Town, Rondebosch 7701, South Africa,

E-mail:shr@geology.uct.ac.za 